\title{
Temporomandibular disorders in elderly patients
}

\author{
Laura Susanti Himawan, Lindawati S. Kusdhany, Nina Ariani
}

\begin{abstract}
Abstrak
Hubungan antara tanda dan gejala Temporomandibular Disorders (TMD) dengan usia masih kontroversial. Pada umumnya penelitian mengenai TMD banyak dilakukan pada populasi dewasa, tetapi kurang pada lanjut usia (lansia). Tujuan penelitian adalah untuk mengetahui frekuensi TMD pada lansia dan faktor-faktor risiko yang mempunyai hubungan dengannya. Penelitian potong lintang ini dilakukan pada pasien-pasien lansia yang datang ke Departemen Geriatri Rumah Sakit Umum Pusat Nasional Cipto Mangunkusumo, Jakarta, Indonesia, dengan kisaran usia 60-91 tahun. Tanda dan gejala klinis pada sendi Temporomandibula diperiksa dan data dianalisis dengan uji non parametrik Chi Square. Walaupun nilai p yang didapat tidak bermakna, dapat disimpulkan bahwa gangguan TMD akan menurun sejalan dengan meningkatnya usia, pria lansia lebih banyak menderita TMD, dan lansia dengan kehilangan 13 gigi atau kurang cenderung mempunyai risiko lebih tinggi. (Med J Indones 2007; 16:237-9)
\end{abstract}

\begin{abstract}
Temporomandibular Disorders (TMD) is a disorder that is still controversial in terms of correlation between clinical signs \& symptoms and age. Most studies were carried out on adult populations with little attention given to the elderly. The purpose of this study is to elucidate the frequency of TMD in elderly population and risk factors pertinent to it. This is a cross sectional study which included patients aged 60-91 of Geriatric Department of National Hospital Cipto Mangunkusumo, Jakarta, Indonesia. The temporomandibular joint (TMJ) was examined for clinical signs \& symptoms. Data was analyzed using non parametric Chi Square test. Although there is no significant $p$ value obtained, there is a clear tendency that occurence of TMD diminishes with age, more male elderly experience TMD and elderly experiencing up to 13 tooth loss might have higher risk for TMD. (Med J Indones 2007; 16:237-9)
\end{abstract}

Keywords: TMD, elderly, risk factors.

Temporomandibular disorder (TMD) is a group of clinical symptoms involving masticatory muscles, joint in orofacial region, or both. This disorder has clinical symptoms such as joint pain, clicking during opening/closing of the mouth, restricted mouth opening, mastication disturbance, and headache. However, nonspecific complaints are often expressed by patients, for example, neck or shoulder pain, tinnitus, and tenderness in sinus areas, etc. ${ }^{1,2}$

Many studies on TMD have been done abroad especially for young adult populations, but not for elderly populations. From 1990 to 2025, Indonesia is predicted to have the biggest increase (by 414\%) of elderly in the world. In 2020, the number of elderly is projected

Department of Prosthodontics, Faculty of Dentistry, University of Indonesia, Jakarta, Indonesia to be $11.34 \%$ of the total population. ${ }^{3}$ With such magnitude in the increase of the number of elderly, more studies on TMD are needed to improve the quality of life of Indonesians. Moreover, controversies exist regarding correlation between age and TMD. Some studies have shown increasing TMD symptoms in elderly patients, but other studies reported concurrent results or even no correlation between TMD and age. Therefore, study for TMD in elderly especially in Indonesia is needed.

Since the etiology of TMD is multifactorial and missing teeth, sex, parafunctional habit (one side chewing, bruxism, clenching) are known as risk factors of the onset of TMD, there will also be an investigation on the correlation between the onset of TMD in elderly and those factors. In the United States, from an epidemiologic study, it was concluded that $75 \%$ of the population tested has at least one clinical symptom of TMD. ${ }^{4}$ In a study on residents of long-term care institutions it was found that only $20 \%$ 
had one or more clinical signs of temporomandibular disorders. ${ }^{5}$

The objective of this study is to elucidate the frequency of TMD in elderly patients in Indonesia and risk factors pertinent to TMD in elderly.

\section{MATERIALS AND METHODS}

This is a cross sectional study. The subjects were conveniently chosen from out- and in- patients of the Geriatric Department of National Central Hospital Cipto Mangunkusumo (Rumah Sakit Umum Pusat Nasional Cipto Mangunkusumo/RSUPNCM) within a 3 months time (April-June 2006). Temporomandibular joint (TMJ) examination was done to find whether the patient had clinical signs and symptoms that relate to TMD. Clinical signs and symptoms observed were pain around TMJ area, TMJ sound, deviation/deflection during opening and closing, and trismus. These examinations were carried out in conformation with the clinical signs list by Helkimo known as the Anamnestic Index \& Clinical Dysfunction Index, ${ }^{6}$ Craniomandibular Index which is divided into Dysfunction Index \& Palpation Index, ${ }^{7}$ and Research Diagnostic Criteria for TMD. ${ }^{8}$

Pain around TMJ area was examined by palpating the area of interest. Joint sound was examined using a stethoscope, and the patient was asked to open and close their mouth slowly. At the same time, deviation or deflection during mouth opening/closing was also noted, along with if the patients were experiencing trismus. TMD was present when the patient experienced one or more signs \& symptoms. Parafunctional habit was calculated when the patient presented one or more of these characteristics: clenching, bruxism, or one side chewing.

Summary statistics (univariate analysis) were used and correlation between TMD and risk factors investigated (age, sex, parafunctional habit and tooth loss) was analyzed with Chi square tests (bivariate analysis).

\section{RESULTS}

This study was approved by the ethical committee, and all subjects gave their consents. Subjects consisted of 33 females and 17 males with age range 60-91 years old with mean age 69.5. From 50 subjects examined, $68 \%$ had at least one TMD signs \& symptoms, $70 \%$ had one or more of parafunctional habits, $56 \%$ experiences more than 13 tooth loss. Determination of
13 as the cut off point for the number of tooth loss was due to 13 being the mean tooth loss number. Frequency distribution of factors studied is in Table 1.

Table 1. Frequency Distribution of TMD and Risk Factors Observed

\begin{tabular}{lcc}
\hline \multicolumn{1}{c}{ Variable } & Sum & $\%$ \\
\hline TMD & & \\
Present & 34 & 68 \\
No & 16 & 32 \\
Age & & \\
Min/70 & 26 & 52 \\
$71 /$ max & 24 & 48 \\
Sex & & \\
Female & 33 & 66 \\
Male & 17 & 34 \\
Parafunctional habit & & \\
Present & 35 & 70 \\
None & 15 & 30 \\
Tooth Loss & & \\
Min/13 & 28 & 56 \\
14/max & 22 & 44 \\
\hline
\end{tabular}

The proportion of elderly with TMD according to several risk factors (age, sex, parafunctional habit and tooth loss,) can be seen on Table 2 . In below 70 age group, 20 subjects had TMD (76.92\%), 6 subjects were normal. In older than 70 age group, 14 subjects had TMD (58.33\%) and 10 subjects were normal. In relation to gender, $63,64 \%$ of female and $76,47 \%$ of male had TMD. Other risk factor was parafunctional habit, within group with parafunctional habit, $62.86 \%$ had TMD, but within group without parafunctional habit, $80 \%$ had TMD. Within group missing of up to 13 teeth, $71.43 \%$ had TMD whereas within group with tooth loss more than $13,63.64 \%$ had TMD.

Table 2. Bivariate Analysis Between Several Risk Factors and TMD

\begin{tabular}{lccccc}
\hline Variable & Normal & $\%$ & TMD & $\%$ & P value \\
\hline Age & & & & & \\
Min/70 & 6 & 23,08 & 20 & 76,92 & \\
$71 /$ max & 10 & 41,67 & 14 & 58,33 & 0.159 \\
& & & & & \\
Sex & 12 & 36,36 & 21 & 63,64 & \\
Female & 4 & 23,53 & 13 & 76,47 & 0.357 \\
Male & & & & & \\
Parafunctional & & & & & \\
$\quad$ habit & 13 & 37,14 & 22 & 62,86 & \\
Present & 3 & 20 & 12 & 80 & 0.234 \\
None & & & & & \\
Tooth Loss & 8 & 28,57 & 20 & 71,43 & 0.558 \\
Min/13 & 8 & 36,36 & 14 & 63,64 & \\
$\quad 14 /$ max & & & & & \\
\hline
\end{tabular}




\section{DISCUSSION}

In this study, the percentage of elderly with TMD was lower compared to an epidemiological study in the United States population, which was $75 \%$, but that study was not conducted in elderly patients. However, result from this study was in accordance with study from Osterberg, Hiltunen which stated that TMD symptoms diminish with increasing age. ${ }^{9,10}$ But Rutkiewicz stated that among the Finnish adult population (30-80 years old) there were more clinically verified signs of TMD in older age groups than among younger subjetcs. ${ }^{11}$

Bivariate analysis between several risk factors (age, sex, parafunctional habit and tooth loss) and TMD showed that TMD tend to decrease with age which is in line with study from Osterberg, Hiltunen. ${ }^{9,10}$ According to Rutkiewicz subjective symptoms are more common among young adults and middle-aged individuals than among children or elderly individual, while clinical signs seems to be more prevalent in the elderly. ${ }^{11}$

The second risk factor is gender. From this study, it can be concluded that males experiences more TMD. Early epidemiologic studies generally did not find significant differences in prevalence between female and male. However, more recent investigations have clearly shown that women have a higher prevalence of most signs and symptoms of TMD than men. ${ }^{1}$ This is an interesting finding because usually females, ${ }^{1,2,4}$ about $75 \%$, experience TMD.

According to McNeill, parafunctional habit do not result in TMD symptoms. However, parafunctional habits have been suggested as initiating and/or perpetuating factors in certain subgroups of TMD patients. ${ }^{4}$ In this study it cannot be concluded that parafunctional habit is a risk factor for TMD

The last risk factor is tooth loss. The result showed that tooth loss does not contribute to the onset of TMD. The relationship between occlusal status and TMD is still unclear and controversial. Discussion as to the need to replace missing posterior teeth in the elderly population to prevent the signs and symptoms of TMD continues with no consensus. ${ }^{12}$

From bivariate analysis (Table 2), using non parametric Chi Square test, it is found that no significant correlation between TMD and risk factors investigated (age, sex, parafunctional habit, and tooth loss) exists. Even though in this study the statistical analysis did not support correlation between TMD and risk factors, but from the frequency distribution of data it can be concluded that age, sex and tooth loss up to 13 teeth tend to have a role in the onset of TMD. The small number of subjects participating in this study might have contributed to the insignificant result of the statistical analysis. Differences in samples, criteria, and methods used make it difficult to compare the results of the present study and previous epidemiologic studies on TMDs. ${ }^{13}$

\section{CONCLUSION}

Although there is no significant $\mathrm{p}$ value obtained, it is concluded that occurence of TMD diminishes with age, and more male elderly experience TMD. Elderly experiencing up to 13 tooth loss might have a higher risk for TMD.

\section{REFERENCES}

1. Carlsson EG, Magnusson T. Management of Temporomandibular Disorders in the General Dental Practice. Chicago: Quintessence Publ.Co,1999, p. 9,19-23,51-66.

2. Okeson JP. Management of Temporomandibular Disorders and Occlusion. $5^{\text {th }}$ ed, St. Louis: CV Mosby, 2003, p. 161172,191-234.

3. Boedhi-Darmojo R. Teori Proses Menua. In: Darmojo RB, Martono H, Eds. Buku Ajar Geriatri (Ilmu Kesehatan Usia Lanjut). ed 2. Jakarta : Balai Penerbit FKUI, 2000. pp 3-13.

4. McNeill C (ed). Temporomandibular Disorders. Guidelines for Classification, Assessment, and Management. $2^{\text {nd }} e d$, Chicago: Quintessence Publ.Co,1993, p. 19,46-60.

5. Budtz-Jorgensen E. Prosthodontics for the elderly. Diagnosis and Treatment. Chicago: Quintessence Publ.co., 1999, p.37-40.

6. Helkimo M. Epidemiological Surveys of Dysfunction of the Masticatory System in Temporomandibular Joint Function and Dysfunction. Zarb G and Carlsson GE, editor. St. Louis: CV Mosby,1979, p. 182-5.

7. Fricton JR, Schiffman EL. Reliability of a Craniomandibular Index. J Dent Res 1986;65(11):1359-64.

8. Dworkin SF, LeResche L. Research Diagnostic Criteria for Temporomandibular Disorders: Review, criteria, examinations and specifications, critique. J Craniomandib Disord 1992;6:301-55

9. Osterberg T, Carlsson GE, Wedel A, Johansson U. A cross-sectional and longitudinal study of craniomandibular dysfunction in an elderly population. J Craniomandib Disord 1992; 6: 237-45.

10. Hiltunen K. Tempormandibular Disorders in the Elderly (dissertation).Helsinki : University of Helsinki; 2004.

11. Rutkiewicz T, Kononen M, Suominen-Tipale L, Nordblad A, Alanen P. Occurrence of clinical Signs of Temporomandibular Disorders in Adult Finns. J Orofac Pain 2006;20:208-17.

12. De Boever JA, Carlsson GE, Klineberg IJ. Need for occlusal therapy and prosthodontic treatment in the management of temporomandibular disorders. J Oral rehab 2000;27: 647

13. LeResche L. Epidemiology of Temporomandibular Disorders: Implications for the investigation of etiologic factors. Crit Rev Oral Med 1997;8:291-305. 
